\title{
Sediment Accretion and Total Organic Carbon Accumulation Among Different Mangrove Vegetation Communities in the Kamora Estuary of Mimika Regency, Papua, Indonesia
}

\author{
Gesang Setyadi', Denny Nugroho Sugianto ${ }^{2}$, Diah Permata Wijayanti ${ }^{3}$, \\ Rudhi Pribadi ${ }^{3}$, Eddy Supardy ${ }^{4}$ \\ 1 Study Program of Doctorate Marine Science, Faculty of Fisheries and Marine Sciences, Universitas \\ Diponegoro. J. Prof. Soedarto, Tembalang, Semarang 50725, Central Java, Indonesia \\ 2 Department of Oceanography, Faculty of Fisheries and Marine Sciences, Universitas Diponegoro. \\ Jl. Prof. Soedarto, Tembalang, Semarang 50725, Central Java, Indonesia \\ 3 Department of Marine Science, Faculty of Fisheries and Marine Sciences, Universitas Diponegoro. \\ Jl. Prof. Soedarto, Tembalang, Semarang 50725, Central Java, Indonesia \\ ${ }^{4}$ Environmental Department, PT Freeport Indonesia, Jl. Mandala Raya Selatan No. 1, Kuala Kencana, Mimika, \\ Papua 99968, Indonesia \\ * Corresponding author's e-mail: gesang.setyadi@gmail.com
}

\begin{abstract}
A sediment accretion and carbon accumulation study was carried out in Kamora Estuary, Mimika Regency, Papua Province, Indonesia, to determine the accretion rate and total organic carbon loading in the area as well their correlation with geographical setting and mangrove aerial root type. The sediment stake method was used to measure the elevation changes, whereas the sediment trap method was used to determine sediment accretion and total organic carbon accumulation. Three locations were selected, namely at upstream, middle and downstream the mangrove communities, with each location installed up to $500 \mathrm{~m}$ perpendicular to the riverbank. The elevation changes based on sediment stakes were 8.4-12.3 mm year ${ }^{-1}$. Sediment accretion based on sediment traps was 18.5-25.4 mm year ${ }^{-1}$ or $1.88-2.98 \mathrm{~g} \mathrm{~cm}^{-2}$ year-1 $^{-1}$, while the mean total organic carbon accumulation was $736.8 \pm 169 \mathrm{~g} \mathrm{~m}^{-2}$ year-1. The results are higher than those of similar studies in other regions, but they are consistent with other studies in Papua New Guinea. This study found that higher sediment accretion occurred at the riverbank compared with the interior area, while the elevation changes were greater in the upstream area. Higher relative density and higher basal area had a negative correlation with sediment accretion, but the number of roots had a positive correlation with sedimentation. The high sedimentation in the Kamora Estuary is resulting in the expansion of the mangrove forest at a rate of $3 \%$ year $^{-1}$. Assisted mangrove colonization can be applied to expand the mangrove forest, especially considering the use of Rhizophora species, which this study found to be more effective at trapping sediment.
\end{abstract}

Keywords: aerial roots, carbon accumulation, Mangrove, Mimika, Papua, sediment accretion

\section{INTRODUCTION}

Mangrove swamps only develop where the coastal physiography is favorable. Mangrove forests are net accumulators of sediment (Alongi et al., 2005) and play a major role as sediment traps (Kathiresan, 2003), promoting the formation of a new habitat suitable for natural mangrove colonization, facilitating the continuous development of mangrove forests, and providing coastal zone stabilization (Phan et al., 2015). The mangrove responses in the areas receiving large supplies of sediments may show rapid coastal progradation and the expansion of mangrove habitats (Adame et al., 2010).

The sedimentation rates in mangroves forests have been widely studied. The highest rate recorded was $4.5 \mathrm{~cm}_{\text {year }}{ }^{-1}$, measured in 
Papua New Guinea (Walsh and Nittrouer, 2004). In most cases, mangroves forests are not adversely affected by sediment accretion, although excess sediment input can cause tree death due to root smothering (Ellison, 1999). For example, the high quantities of volcano mud in the Porong River, East Java, lead to vertical accretion of more than $10 \mathrm{~cm}$ year ${ }^{-1}$, causing reduced growth in Avicennia sp. (Sidik et al., 2015).

The mangrove forests in Indonesia are considered the most extensive in the world and represent about $23.5 \%$ of global mangroves (Kathiresan and Bingham, 2001); the largest area is in Papua Island, representing about $58 \%$ of the total area (Hanum et al., 2014). In Mimika, one of the regencies of Papua Province, Indonesia, and located on the southern coast of Papua, the mangroves are estimated to cover about 186,291 ha (Aslan et al., 2018). These mangroves are dominated by Avicennia - Sonneratia colonization on mud and sandbanks, Rhizophora, Bruguiera, and Nypa forests, as well as mixed forests along the freshwater margins (Ellison, 2005). In the Bruguiera and Rhizophora communities, the tree sizes reach 25-30 m in height (Brunskill et al., 2004).

Papua Island is the result of the collision of the Pacific and Australian plates, forming steep topographic expressions (Aalto \& Dietrich, 2005) with one of the most mountainous areas having peaks around $4.9 \mathrm{~km}$ above sea level (Davies, 2012) and substantial river catchment areas (Brunskill et al., 2004). Southern Papua has significant annual rainfall (4-13 $\mathrm{m} \mathrm{yr}^{-1}$ ) (Setyadi et al., 2009). The combination of this rugged terrain and high rainfall results in high erosion, creating sediment deposition in the coastal zones (Kastoro et al., 2007).

There are limited studies on sediment accretion in correlation with mangrove responses in Papua, Indonesia. The only studies have been conducted on the sediment depositional history (Brunskill et al., 2004) and Holocene stratigraphic records of vegetation change and sedimentation (Ellison, 2005) and carbon stock (Taberima et al., 2014). Some studies on sedimentation were conducted in Papua New Guinea (Aller \& Blair, 2004; Walsh \& Nittrouer, 2004; Aalto \& Dietrich, 2005), which has a similar mangrove ecosystem to Papua, Indonesia. The sediment accumulation in the Gulf of Papua ranging from 1.2 to $4.4 \mathrm{~cm}$ year ${ }^{-1}$ was determined by Walsh and Nittrouer (2004) using steady-state ${ }^{210} \mathrm{~Pb}$ profiles, and the mangroves in that area were shown to account for trapping $2-14 \%$ of the total sediment load.
Determining sedimentation in mangroves is important to identify the increase in coastal surface (Willemsen et al., 2016) and the changes to the mangrove community (Walsh \& Nittrouer, 2004) as well as to estimate the concentrations of nutrients that increase the productivity of flora and fauna (Ewe et al., 2008). The selection of appropriate methods to measure sedimentation depends on the time scale of interest due to the variable nature of this process (Swales \& Lovelock, 2020).

The aim of this study was to determine the sedimentation rate and total organic carbon loading in certain mangrove forest communities of Kamora Estuary, Mimika, Papua Province, Indonesia, as well as their correlation with aerial root structure and mangrove area changes. The behavior of sedimentation due to differences in the mangrove aerial root systems and geographical settings, such as upstream and downstream and between the riverbank and interior mangroves, was also evaluated. Furthermore, the methods used to measure sediment accretion or elevation changes were assessed to determine the effectivity of measuring the sedimentation rate in a mangrove ecosystem. The results of this study can be used for the conservation or selection of mangrove species for the mangroveassisted colonization programs.

\section{MATERIALS AND METHODS}

\section{Study area}

The study area is located in the Kamora Estuary, Mimika Regency, Papua Province, Indonesia. The coordinates for the study locations were K1 (S: $04^{\circ} 49^{\prime} 07.117^{\prime \prime}$ and E: $\left.130^{\circ} 40^{\prime} 59,202^{\prime \prime}\right), \mathrm{K} 2$ (S: $04^{\circ} 48^{\prime} 00.603^{\prime \prime}$ and E: $130^{\circ} 41^{\prime} 06.207^{\prime \prime}$ ), and K3 (S: 04 ${ }^{\circ} 47^{\prime} 51,142^{\prime \prime}$ and E: $\left.130^{\circ} 41^{\prime} 57,816^{\prime \prime}\right)$. Detailed study locations can be seen in Figure 1.

The Kamora Estuary has a catchment area of $1,474 \mathrm{~km}^{2}$, with an estimated mangrove area of 14,000 ha. The thickness of the mangrove from the coastline is about $20 \mathrm{~km}$.

The measurement of the sedimentation rate was conducted from the year 2006 until 2020. The measurements and analyses were carried annually during a low tide. The vegetation analysis and aerial root analysis were conducted in 2020 . 


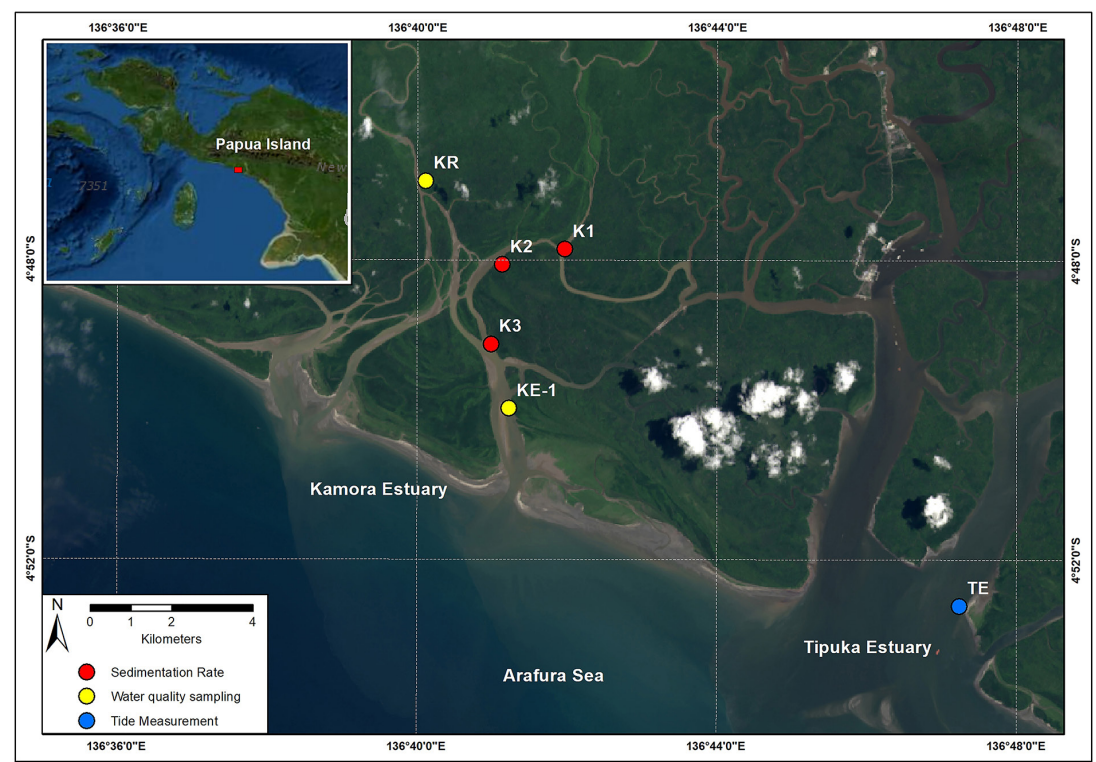

Figure 1. Study locations in the Kamora Estuary, Mimika, Papua

\section{Sedimentation rate}

The sedimentation rate was measured using the sediment trap and sediment stake methods. The sediment traps and sediment stakes were installed perpendicular to the riverbank. The sediment traps were installed at distances of $0 \mathrm{~m}, 100 \mathrm{~m}, 300 \mathrm{~m}$ and $500 \mathrm{~m}$, while the sediment stakes were installed every $50 \mathrm{~m}$. At each distance (station), three sediment traps and three sediment stakes (A, B, and C) were installed about $10 \mathrm{~m}$ apart. The placement and design of the sediment traps and sediment stakes are exemplified in Figure 2.
The sediment trap method was used by Santen et al. (2007), Adame et al. (2010) and Rogers et al. (2013). Santen et al. (2007) used a $0.4 \mathrm{~mm}$ thick canvas with a rough surface and with the dimensions $0.4 \times 0.4 \mathrm{~m}$. The canvas was attached to the ground with the aid of a wooden stake. The sediment-filled traps were removed after 2-3 weeks, and the sediment weight was calculated based on the fraction of lutum $(<2 \mu \mathrm{m})$, fine clay $(2-20 \mu \mathrm{m})$, coarse clay $(20-50 \mu \mathrm{m})$ and sand $(>50 \mu \mathrm{m})$. The dry sediment accumulation was calculated as $\mathrm{g} \mathrm{cm}^{-2}$ year- $^{-1}$. Meanwhile, Adame et al. (2010) used a $9 \mathrm{~cm}$ Whatman filter. The filter

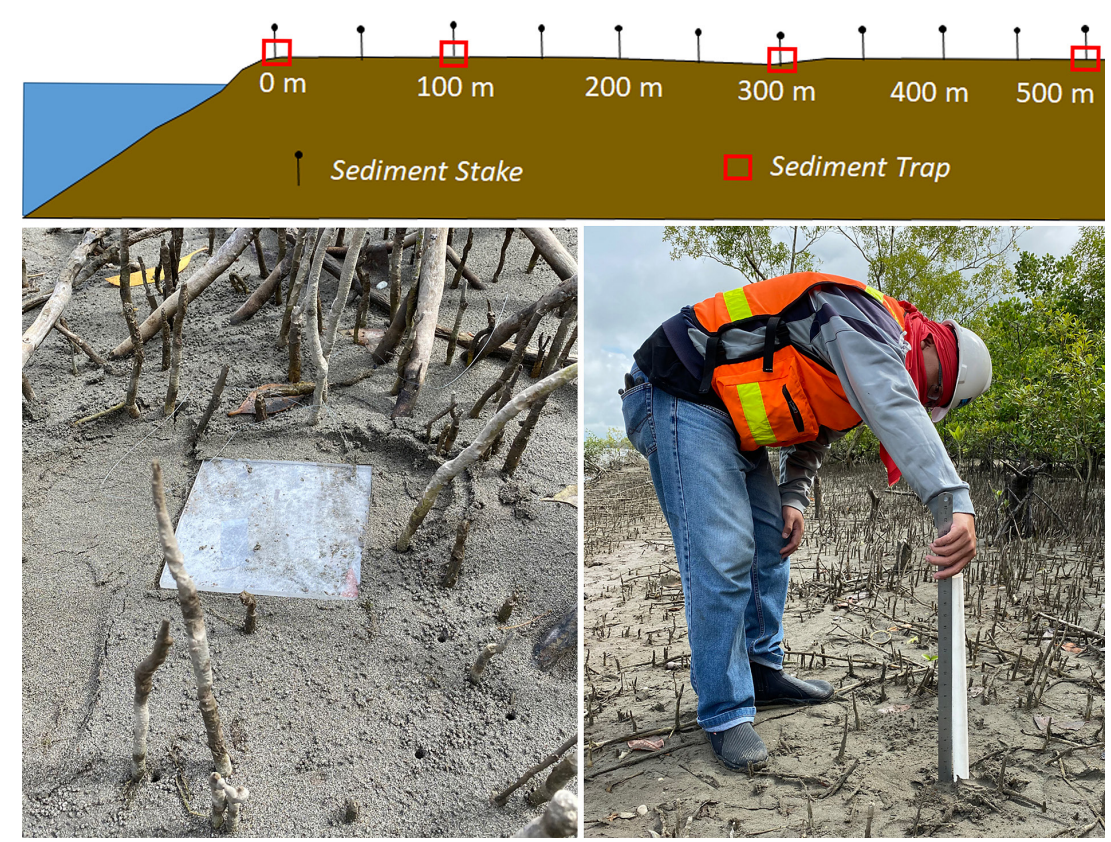

Figure 2. Placement and design of sediment trap (left) and sediment stake (right) 
was placed on the lid of a petri dish and then attached to the ground using a hook. The petri dish cover was $0.8 \mathrm{~cm}$ high by $9 \mathrm{~cm}$ wide ( 0.1 ratio), thereby reducing the risk of overestimating sediment capture under turbid conditions. The sediment trap was collected after about 7-10 tide cycles. All sediment trapped in the petri dish was calculated. Salinity correction was performed by immersing the sample in water and heating it to $60^{\circ} \mathrm{C}$. The sedimentation rate was calculated based on each tidal cycle, by calculating the difference in weight after and before the sediment trap had been placed in the field. Finally, Roger et al. (2013) used PVC pipes $30 \mathrm{~cm}$ long and $5 \mathrm{~cm}$ in diameter that were buried with $1 \mathrm{~cm}$ exposed above the forest platform and $100 \mathrm{~cm}^{2}$ ceramic tiles.

This study adopted the method by Rogers et al. (2013) method, but the used sediment trap design involved fiber glass, with the dimensions $20 \mathrm{~cm} \times 20 \mathrm{~cm}$, placed on the ground, with the top surface of the fiber glass level with the soil surface. In order to mark each trap, a string attached to the edge of each sediment trap was affixed to a nearby mangrove aerial root or mangrove tree. After 12 months of placement, the sediment traps were excavated, and the vertical accretion was measured using a caliper to assign a total of five points for each sediment trap (at each corner and the middle of each sediment trap). Then, using a pre-cleaned certified $1000 \mathrm{~mL}$ wide mouth HDPE bottle $11.2 \mathrm{~cm}$ in diameter, the sediment above the trap was carefully collected by pushing the open bottle into the sediment and ensuring that all the sediment within the diameter of the HDPE bottle was collected. The HDPE bottle was then labeled and placed in a cold box for transport to the laboratory. The samples were oven-dried at $103-105^{\circ} \mathrm{C}$ and weighed once the weight had stabilized. Subsequently, the samples were measured in the laboratory in terms of particle size distribution and total organic carbon concentration. The calculation of the sediment accretion rate was performed using the approach of Adame et al. (2010), with the following equation:

$$
\begin{gathered}
\frac{\text { Dry weight of sediment }(\mathrm{mg}) \times 365}{\text { Sedimentation rate }\left(\mathrm{mg} \mathrm{m}^{-2} \text { year }{ }^{-1}\right)}= \\
=\text { Diameter of bottle }\left(\mathrm{m}^{2}\right) \times \text { number of days } \\
\frac{\text { Thickness of sediment }(\mathrm{cm}) \times 365}{\text { Sedimentation rate }\left(\mathrm{cm} \text { year } \mathrm{r}^{-1}\right)}= \\
=\text { Number of days }
\end{gathered}
$$

The sediment stake or pin sediment method was used by Krauss et al. (2002), which employed stainless steel rods $0.25 \mathrm{~m}^{2}$ in diameter and $100 \mathrm{~cm}$ in length, which were buried in the ground up to a depth of about $70 \mathrm{~cm}$. The distance between the top of the rod and the ground was measured using a meter with an accuracy of $0.1 \mathrm{~cm}$. The vertical sediment addition was determined by calculating, with an accuracy of $0.1 \mathrm{~cm}$, as the distance from the top of the plug to the marker horizon. This marker showed the occurrence of additional sediment or erosion, i.e., if the marker was buried with sediment, there had been sediment accretion, while a lost marker would indicate erosion.

The current study used PVC pipes 1 inch $(2.5 \mathrm{~cm})$ in diameter and $100 \mathrm{~cm}$ in length. The sediment stakes were stuck into the soil at a depth of 50-70 cm. Then, the distance from the top of the stake to the soil surface was measured with a ruler with an accuracy of $1 \mathrm{~mm}$. Each sediment stake was measured again after 1 year using the same method. The delta of measurement was calculated as sediment increment if the value was negative and as sediment erosion if the value was positive. The total days measured was adjusted to 365 days to obtain sedimentation accretion for one year $\left(\mathrm{mm} \mathrm{year}^{-1}\right)$. Given the possibility of land subsidence, this research only describes the changes in elevation. The method and sedimentation rate calculation were adopted from Krauss et al. (2003), using the following equation:

$$
\begin{gathered}
\frac{(\text { First measurement }- \text { second measurement }) \times 365}{\text { Elevation change }\left(\mathrm{cm}^{-1}\right)}= \\
=\text { Number of days }
\end{gathered}
$$

\section{Mangrove vegetation and aerial root measurement}

Mangrove trees were measured in $20 \mathrm{~m} \times$ $20 \mathrm{~m}$ plots with two replicates along a $500 \mathrm{~m}$ perpendicular to the riverbank, whereby the total transect was 50 plots, covering 2 ha. In each plot, all trees with a diameter of breast height (dbh), or a chest diameter at $1.3 \mathrm{~m}$, of $>10 \mathrm{~cm}$ were measured in terms of their diameter and height, and their species was identified. If the species was unknown, photos of roots, stems, leaves, flowers and fruit were taken with a camera. Leaf, flower and fruit samples were also taken for further identification. The sampling data recording for trees was the species name, diameter, height and position 
(coordinates) of the trees in the plot. The analysis of the vegetation data focused on the relative density (RD) and basal area (BA) of each species.

Considering that the root system of mangroves plays an important role in capturing sediment (Krauss et al., 2001), the measurement of root types and the location of sedimentation measurements were used to identify the relationship between the types of mangrove roots and their ability to capture sediment. At each sediment trap location $(0 \mathrm{~m}, 100 \mathrm{~m}, 300 \mathrm{~m}$ and $500 \mathrm{~m})$, a plot measuring $1 \mathrm{~m}^{2}$ was established to calculate the number and diameter of the aerial roots (adopting from Krauss et al., 2002). The diameter of the root was calculated using a caliper with an accuracy of at least $0.01 \mathrm{~cm}$. The result represented the number and volume of aerial roots for every $\mathrm{m}^{2}$. The data were correlated with the sedimentation rate to determine the effect of aerial root type on the sedimentation rate.

\section{Tide and water quality}

The tide data were recorded using a CS475 Non-Contact Water Level Monitoring sensor from Campbell Scientific installed at the Tipuka Estuary, located about $11 \mathrm{~km}$ east of the Kamora Estuary. This sensor recorded the water level every 15 minutes throughout 2020 . The water quality data were collected upstream and downstream of the Kamora Estuary study location. The water samples were taken every 3 months during the 2006-2020 period. The sampling referred to SNI 6989.57:2008, Water and Wastewater, Section 57: Surface Water Sampling Method. The water samples were analyzed for total suspended solids at the laboratory (Standard Methods for the Examination of Water and Wastewater, 22 $2^{\text {nd }}$ edition 2012, APHA, AWWA, WEF. Method \#2540D).

\section{Spatial analysis of the mangrove area}

A spatial analysis was carried out to calculate the changes in the mangrove area and the formation of new mangrove colonization using Landsat 7 ETM Imagery from 2006 and 2010 and Landsat 8 for 2020. The calculation of the spatial data was done by digitization using ESRI ArcGIS 10.8 software.

\section{RESULTS}

\section{Tide and water quality}

The tide measurements are shown in Figure 3. The data show that the highest tide was recorded at $4.45 \mathrm{~m}$ on December $17^{\text {th }}, 2020$, at 05:00 AM and the lowest tide was recorded at $0.26 \mathrm{~m}$ on July $6^{\text {th }}, 2021$, at 1:30 AM. The mean sea level (MSL) was $1.821 \mathrm{~m}$ of tide measurement. On the basis of the elevation measurement, $\mathrm{K} 1$ had an elevation of 1.1.m above MSL, and K3 was $0.94 \mathrm{~m}$ above MSL based on the measurement using differential GPS. On the basis of the MSL, the stations were inundated with seawater for around $16 \%$ of the total time during the year.

The total suspended solids (TSS) data are shown in Figure 4. On the basis of the water quality data analysis, the TSS from Kamora River (KR) ranged from 1 to $2560 \mathrm{mg} \mathrm{L}^{-1}$ with an average of $172 \mathrm{mg} \mathrm{L}^{-1}$, for Kamora Estuary 1 (KE1) it was 3-310 $\mathrm{mg} \mathrm{L}^{-1}$ with an average of $124 \mathrm{mg} \mathrm{L}^{-1}$, for Kamora Estuary 2 (KE2) it was 1-298 mg L-1 with an average of $38 \mathrm{mg} \mathrm{L}^{-1}$.

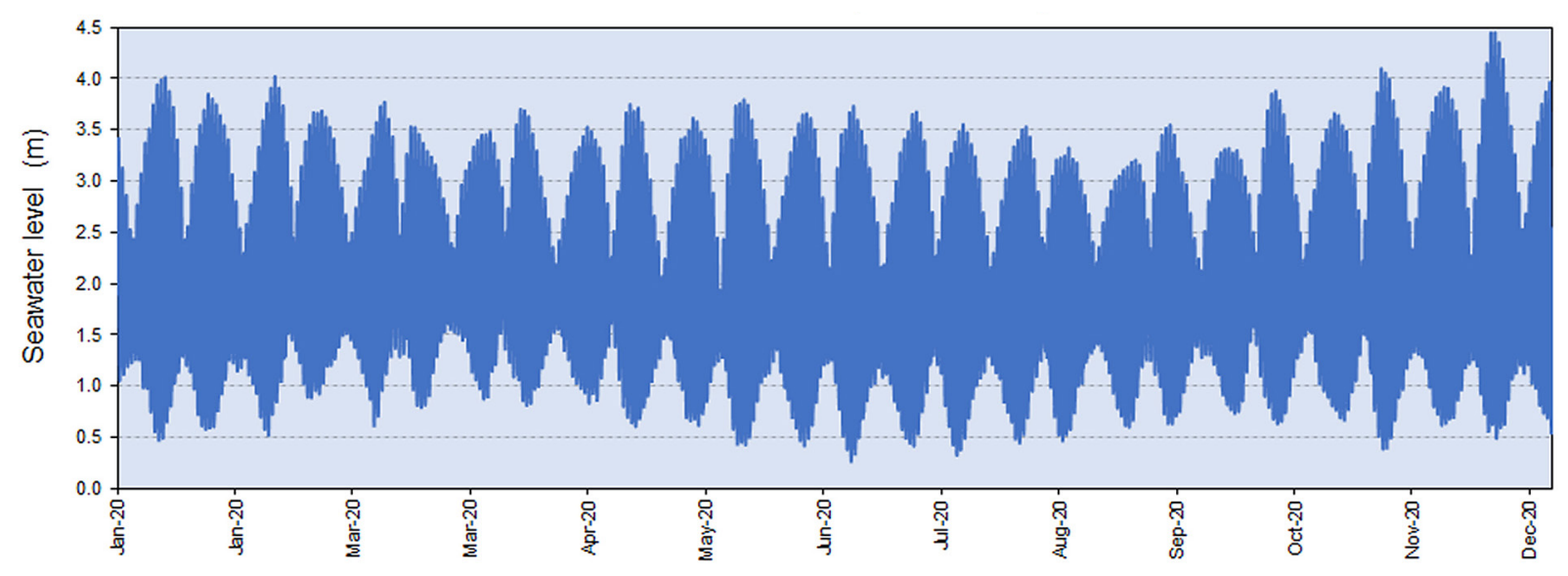

Figure 3. Tide measurement in Mimika, Papua 


\section{Sediment stakes}

A summary of the elevation changes measured with the sediment stake method is presented in Table 1, while the plot-and-whisker graph for each station and the elevation changes along the plot are shown in Figure 5. The elevation changes varied from $8.5 \pm 3.9$ to $12.3 \pm 0.8 \mathrm{~mm}$ year ${ }^{-1}$, with an average elevation change from the three stations of $10.4 \mathrm{~mm}$ year $^{-1}$. The measurement shows that the elevation change at $\mathrm{K} 1$ was the highest, followed by $\mathrm{K} 2$ and $\mathrm{K} 3$. The high variation in the elevation change was mainly due to the burrowing activities of crustaceans, resulting in some stakes having very high sediment deposition.

\section{Sedimentation traps}

A summary of the sedimentation rate or sediment accretion in both $\mathrm{mm}_{\text {year-1 }}{ }^{-1}$ and $\mathrm{kg} \mathrm{m}^{2}$ year $^{-1}$ is shown in Table 2. The plot-and-whisker graphs of the sedimentation rates are shown in Figure 6 and Figure 7. The data from Table 2 show that the highest sedimentation rate was K2, followed by $\mathrm{K} 1$ and $\mathrm{K} 3$. The highest mass for the sedimentation rate per $\mathrm{m}^{2}$ was also $\mathrm{K} 2$, followed by $\mathrm{K} 1$ and then $\mathrm{K} 3$.

\section{Total organic carbon and particle size distribution}

Table 3 shows the total organic carbon and particle analysis of the sediment from the study sites. The mean total organic carbon was $3.07 \pm$ $1.37 \mathrm{mg} \mathrm{kg}^{-1}$ while the mean total organic carbon accumulation was $736.8 \pm 169 \mathrm{~g} \mathrm{~m}^{-2}$ year'- The highest total organic carbon concentration was $\mathrm{K} 1$, followed by $\mathrm{K} 2$ and $\mathrm{K} 3$, whereas the total organic carbon loading had a similar trend. The D50 median particle size was the highest at K3, followed by $\mathrm{K} 1$ and $\mathrm{K} 2$.

\section{Aerial roots and correlation with sedimentation rate}

The measurement results for the aerial roots with mangrove vegetation species are shown in Table 4. The table shows that K2 had the highest number of roots as well as the highest root area. This may explain the highest sedimentation rate in this location, as shown in Table 2. The dominant mangrove vegetation comprised Bruguiera gymnorrhiza $\left(75 \mathrm{ha}^{-1}\right)$ and Rhizophora apiculata $\left(28 \mathrm{ha}^{-1}\right)$. The correlation between aerial roots and the sedimentation rate is shown in Figure 8, which presents a negative correlation between relative density, basal area and diameter and sediment accretion, although there is a positive correlation between the means of the roots and sediment accretion.

\section{Spatial analysis of mangrove area changes}

Figure 9 presents the spatial analysis using ArcGIS to calculate the changes in the mangrove area over time. On the basis of the spatial analysis, there was an increase of 266.48 ha in the mangrove area from 2006 until 2020, while there was also a loss of mangroves amounting to 74.3 ha. Thus, the total additional mangrove area was 192.18 ha. The total mangrove area calculated in 2006 was 3.646 .5 ha, and after 15 years,

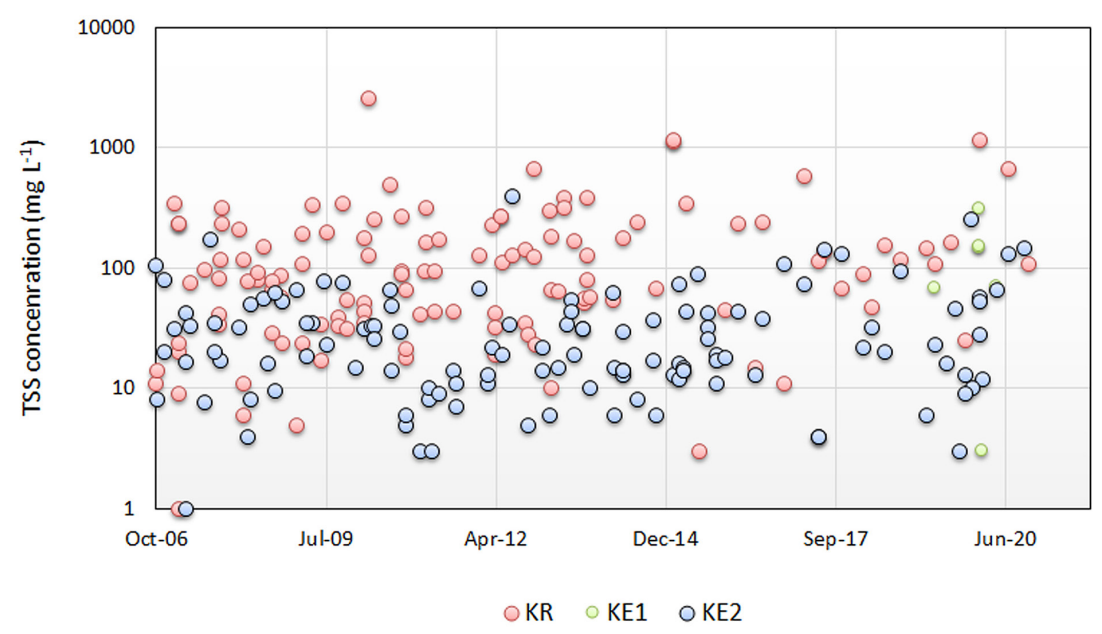

Figure 4. Total suspended solids (TSS) from the Kamora River (KR) and Kamora Estuaries (KE1 and KE2) in Mimika, Papua 
Table 1. Summary of the elevation changes of the mangrove forest in the Kamora Estuary, Mimika, Papua

\begin{tabular}{|c|c|c|c|c|}
\hline Station & $0-100 \mathrm{~m}$ & $150-300 \mathrm{~m}$ & $350-500 \mathrm{~m}$ & Average \\
\hline $\mathrm{K} 1$ & $11.6 \pm 7.8$ & $12.1 \pm 2.6$ & $13.1 \pm 4.7$ & $12.3 \pm 0.8$ \\
\hline $\mathrm{K} 2$ & $10.4 \pm 6.6$ & $10.7 \pm 10.9$ & $13.2 \pm 4.8$ & $11.5 \pm 1.5$ \\
\hline K3 & $12.6 \pm 8.9$ & $4.8 \pm 2.0$ & $9.2 \pm 1.3$ & $8.5 \pm 3.9$ \\
\hline Average & $10.5 \pm 2.7$ & $9.2 \pm 3.9$ & $11.4 \pm 2.1$ & $10.4 \pm 1.1$ \\
\hline
\end{tabular}

the additional mangrove area was calculated as $5.27 \%$, or about $0.35 \%$ every year.

\section{DISCUSSION}

Several methods were applied to measure the sedimentation rates in mangrove ecosystems. The most widely used technique is based on the radioisotope ${ }^{210} \mathrm{~Pb}$ (Bajernee, 2012; Smoak et al., 2013; Swales et al., 2015;). Other radioisotope methods are ${ }^{137} \mathrm{Cs}$ (Swales et al., 2015; Marchio et al., 2016), ${ }^{7} \mathrm{Be}$ (Swales et al., 2007; Swales et al., 2015;), and ${ }^{234}$ Th (Smoak \& Patchineelam, 1999). Other methods for measuring sedimentation rates in mangroves are surface elevation tables (Stokes et al., 2009; McKee, 2011), sediment stakes (Krauss et al., 2003) and sediment traps (Santen et al., 2007; Adame et al., 2010). The method applied in the current study, namely sediment stakes and sediment traps, over a
15 -year period produced different results. The sediment stakes revealed lower sedimentation rates $\left(8.5-12.3 \mathrm{~mm}\right.$ year $\left.{ }^{-1}\right)$ than the sediment traps (18.5-25.4 mm year ${ }^{-1}$ ). The sediment trap method has the advantage of measuring the sedimentation rate in mass units, but it can introduce an overestimation due to erosion or resuspension (Adame et al., 2010). Meanwhile, the sediment stake method has the advantage of describing the process of erosion and accretion, as described in Krauss et al. (2003). This study has shown that both sediment stakes and sediment traps can be used to effectively measure the sedimentation rates in a mangrove forest.

The sediment accretion in this study was higher than that found by MacKenzie et al. (2016) in Vietnam $\left(2.44 \pm 1.38 \mathrm{~cm}\right.$ year $\left.^{-1}\right)$ and Palau mangrove forests $\left(0.47 \pm 0.08 \mathrm{~cm}\right.$ year $\left.{ }^{-1}\right)$, by Smoak et al. (2013) in Everglades National Park, Florida (2.5 and $3.6 \mathrm{~mm} \mathrm{yr}^{-1}$ ), by Swales et al. (2020) in New Zealand (averaging 17-41 $\mathrm{mm} \mathrm{yr}^{-1}$ ), by

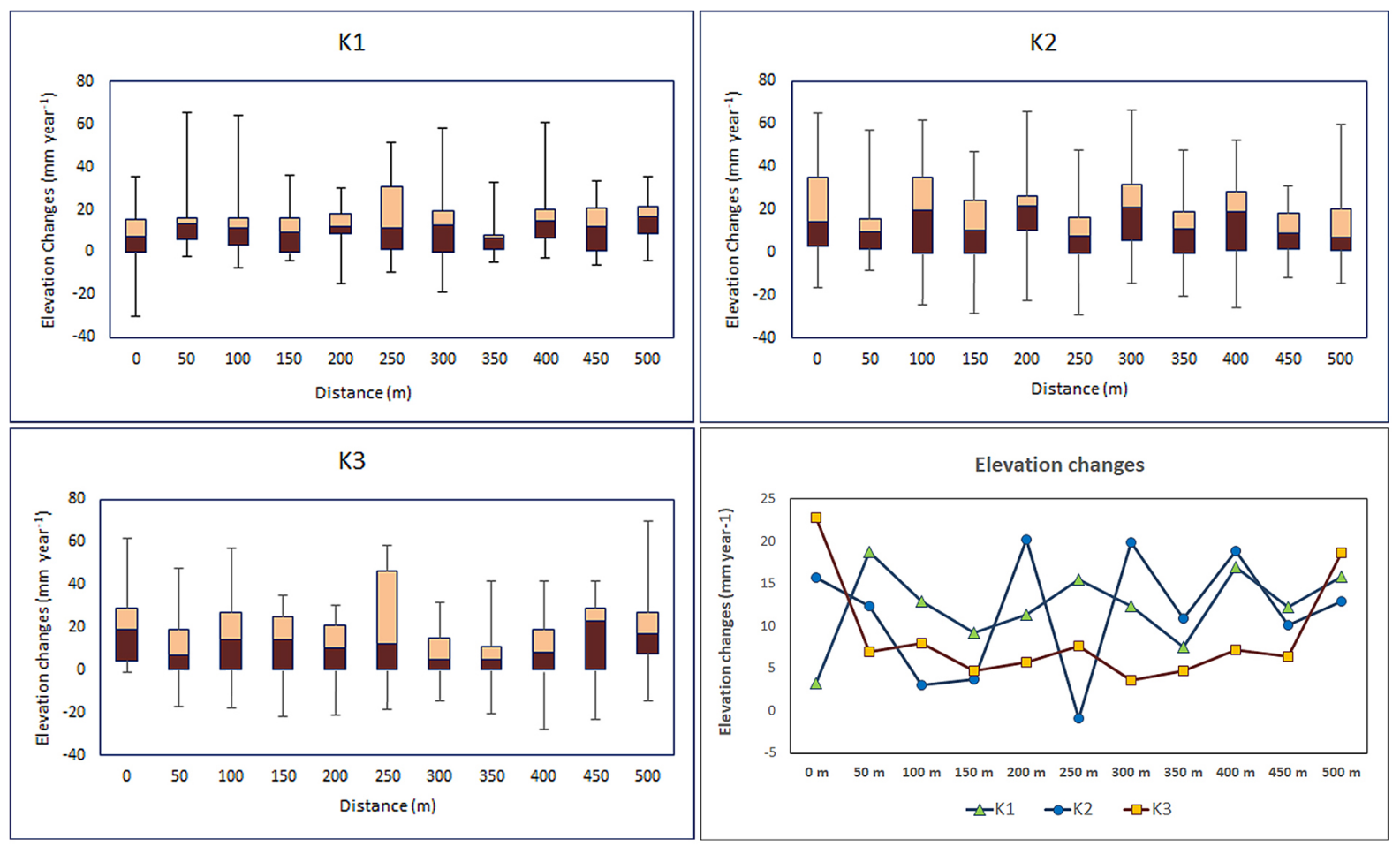

Figure 5. Plot-and-whisker graph for each station and the elevation changes along the transect in the mangrove forest of Kamora Estuary, Mimika, Papua 
Table 2. Summary of sedimentation rate changes of mangrove forest in the Kamora Estuary, Mimika, Papua

\begin{tabular}{|c|c|c|c|c|c|c|}
\hline \multirow{2}{*}{ Distance $(\mathrm{m})$} & \multicolumn{3}{|c|}{ Sedimentation rate $\left(\mathrm{mm} \mathrm{year}^{-1}\right)$} & \multicolumn{3}{c|}{ Sedimentation rate $\left(\mathrm{g} \mathrm{cm}^{2}\right.$ year $\left.^{-1}\right)$} \\
\cline { 2 - 7 } & $\mathrm{K} 1$ & $\mathrm{~K} 2$ & $\mathrm{~K} 3$ & $\mathrm{~K} 1$ & $\mathrm{~K} 2$ & $\mathrm{~K} 3$ \\
\hline 0 & $16.5 \pm 12.6$ & $27.7 \pm 17.1$ & $16.6 \pm 9.2$ & $2.16 \pm 1.36$ & $2.76 \pm 1.60$ & $1.97 \pm 0.76$ \\
\hline 100 & $24.0 \pm 15.6$ & $29.6 \pm 12.6$ & $20.7 \pm 9.7$ & $2.72 \pm 1.64$ & $3.74 \pm 1.34$ & $2.08 \pm 0.76$ \\
\hline 300 & $22.9 \pm 15.1$ & $22.7 \pm 13.2$ & $17.1 \pm 10.6$ & $2.04 \pm 0.98$ & $2.44 \pm 1.04$ & $1.74 \pm 0.79$ \\
\hline 500 & $14.0 \pm 7.5$ & $21.4 \pm 9.6$ & $19.6 \pm 11.0$ & $0.76 \pm 0.51$ & $2.98 \pm 0.84$ & $1.73 \pm 0.73$ \\
\hline Mean & $21.4 \pm 4.9$ & $25.4 \pm 4.0$ & $18.5 \pm 2.0$ & $1.92 \pm 1.02$ & $2.98 \pm 0.80$ & $1.88 \pm 0.52$ \\
\hline
\end{tabular}

Li et al. (2016) in Deep Bay, China $(1.38 \mathrm{~mm}$ $\mathrm{yr}^{-1}$ ) and by Bomer et al. (2019) in Bangladesh $\left(2.16 \pm 0.2 \mathrm{~cm}\right.$ year $^{-1}$ at the stream bank and $1.32 \pm 0.17 \mathrm{~cm}$ year $^{-1}$ in the interior). Woodroffe et al. (2016) summarized the vertical accretion for different mangrove hydrogeomorphic settings, whereby the riverine vertical accretion ranged from 6.5 to $13.0 \mathrm{~mm} \mathrm{yr}^{-1}$ and for the interior it ranged from 0.7 to $20.8 \mathrm{~mm} \mathrm{yr}^{-1}$.

The mass accumulation of sediment in this study (means ranging from 1.88 to $2.98 \mathrm{~g} \mathrm{~cm}^{-2}$ year $^{-1}$ ) was also higher compared to other studies, such as Banerjee et al. (2011) in the Sundarbans (0.66 $\mathrm{g} \mathrm{cm}^{-2}$ year $\left.^{-1}\right)$, Morelli et al. (2012) in Queensland $\left(0.16 \pm 0.01\right.$ to $0.71 \pm 0.30 \mathrm{~g} \mathrm{~cm}^{-2}$ year $^{-1}$ ), and Li et al. (2016) in Deep Bay, China
(0.5 to $0.94 \mathrm{~cm}^{-2}$ year $^{-1}$ ). The results were also higher than in a previous study at a nearby estuary (Ajkwa River) by Brunskill et al. (2004), which showed a mass accumulation rate of 0.45 to $1.3 \mathrm{~g}$ $\mathrm{cm}^{-2}$ year $^{-1}$. The sedimentation rate in Papua New Guinea is relatively high due to numerous major rivers and estuaries resulting from the high rainfall and high mountains. It was estimated that the discharge from New Guinea contains about 1.5 billion tons year ${ }^{-1}$ of sediment into the adjacent seas, including the foreland basin between New Guinea and Australia (Harris et al., 1996). Walsh and Nittrouer (2004) determined the sediment accumulation in the Gulf of Papua using steady-state ${ }^{210} \mathrm{~Pb}$ profiles, and found the greatest mean rates in midtidal areas $\left(4.4 \mathrm{~cm}_{\text {year }}{ }^{-1} ; 3.9 \mathrm{~g} \mathrm{~cm}^{-2}\right.$ year $\left.^{-1}\right)$ with
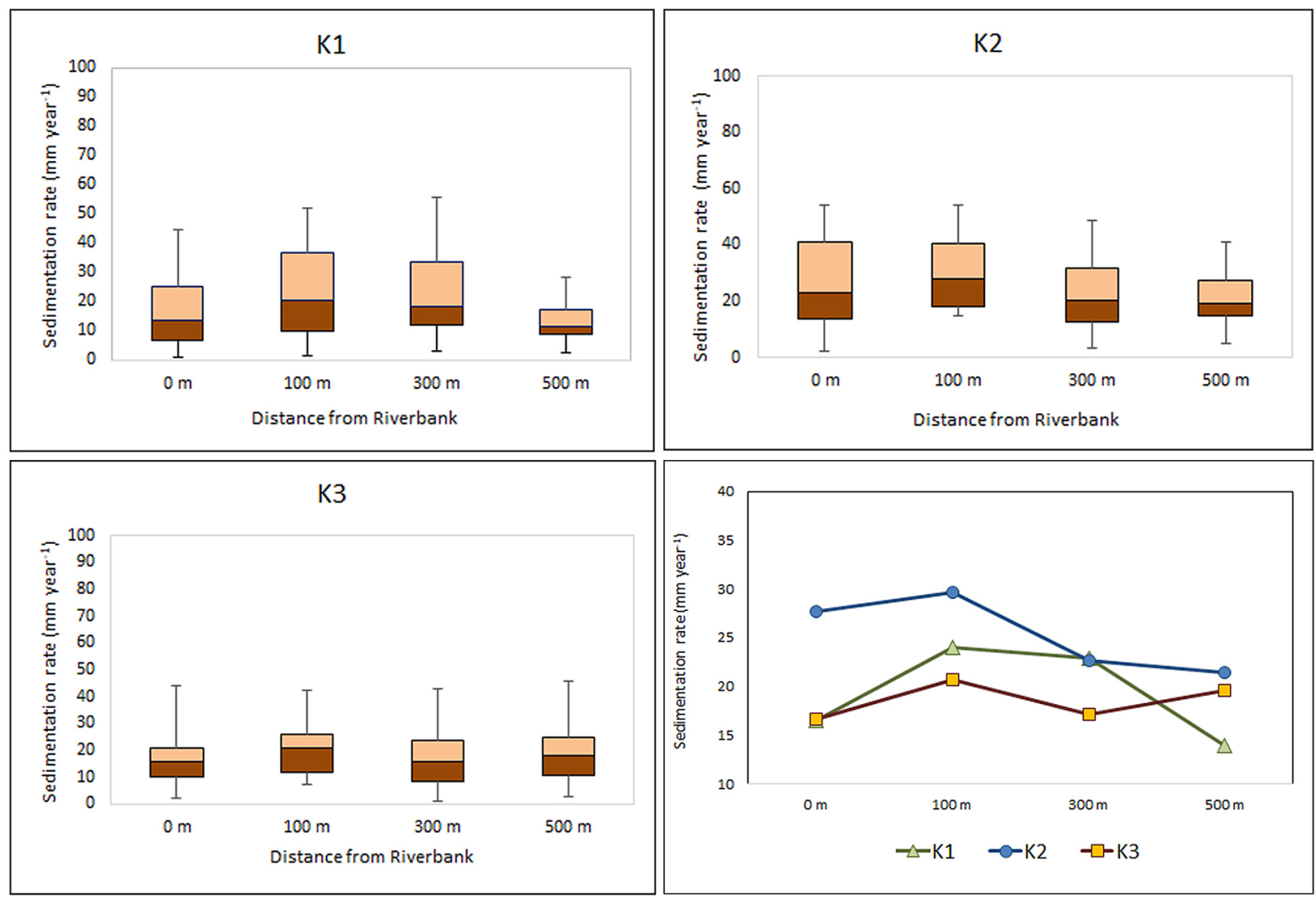

Figure 6. Plot-and-whisker graph for each station and the average sedimentation rate (mm year-1) along the transect in the mangrove forest of the Kamora Estuary, Mimika, Papua 


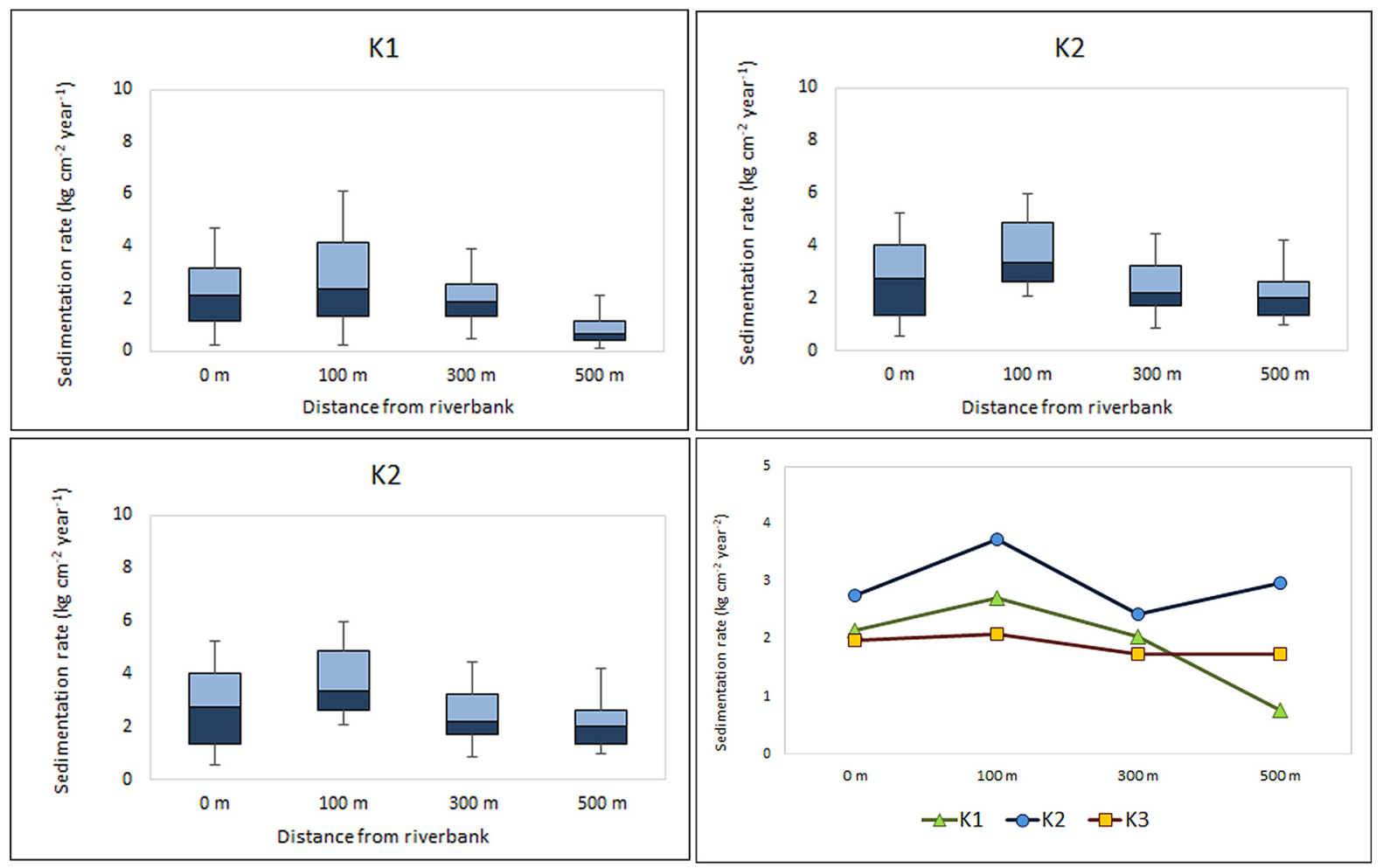

Figure 7. Plot-and-whisker graph for each station and the sedimentation rate $\left(\mathrm{kg} \mathrm{m}^{-2} \mathrm{year}^{-1}\right)$ along the transect in the mangrove forest of Kamora Estuary, Mimika, Papua

slower accumulation in high-tidal and low-tidal areas (1.8 and $1.5 \mathrm{~cm}^{-1}$ year $^{-1}$, respectively; 1.2 and $1.0 \mathrm{~g} \mathrm{~cm}^{-2}$ year $^{-1}$, respectively).

This study demonstrated that higher sediment accretion occurred at the riverbank compared to the interior area, which is consistent with other studies (Woodroffe et al., 2016; Bomer et al., 2020). The highest sediment accretion was found at a distance of $100 \mathrm{~m}$ from the sediment trap measurement. These areas seem to have maximum deposition due to a combination of tidal resuspension, elevation and aerial root structures.

Table 3. Total Organic Carbon (TOC), TOC loading and particle analysis of sediment in the Kamora Estuary, Mimika, Papua

\begin{tabular}{|c|c|c|c|c|c|c|c|c|}
\hline Station & $\begin{array}{c}\text { Distance } \\
(\mathrm{m})\end{array}$ & $\begin{array}{c}\text { Mean of } \\
\text { TOC }(\%)\end{array}$ & $\begin{array}{c}\text { Mean of TOC } \\
\text { Accumulation } \\
\left(\mathrm{g} \mathrm{m}^{2} \text { year }^{-1}\right)\end{array}$ & $\begin{array}{c}\text { Mean of D50 } \\
\text { Particle Size } \\
(\mu \mathrm{m})\end{array}$ & $\begin{array}{c}\text { Mean of } \\
\text { Particle Size } \\
>125 \mu \mathrm{m}(\%)\end{array}$ & $\begin{array}{c}\text { Mean of } \\
\text { Particle } \\
\text { Size } \\
125 \mu \mathrm{m}(\%)\end{array}$ & $\begin{array}{c}\text { Mean of } \\
\text { Particle Size } \\
63 \mu \mathrm{m}(\%)\end{array}$ & $\begin{array}{c}\text { Mean of } \\
\text { Particle Size } \\
2 \mu \mathrm{m}(\%)\end{array}$ \\
\hline $\mathrm{K} 1$ & 0 & 2.02 & 443.32 & 29.59 & 18.20 & 15.05 & 75.08 & 6.31 \\
\hline & 100 & 3.13 & 911.92 & 24.22 & 19.10 & 12.60 & 77.97 & 8.24 \\
\hline & 300 & 4.27 & 897.56 & 31.67 & 16.15 & 15.89 & 70.14 & 6.49 \\
\hline & 500 & 7.19 & 549.21 & 59.50 & 44.30 & 11.03 & 68.35 & 7.11 \\
\hline & Mean & 3.86 & 700.51 & 33.10 & 22.17 & 13.89 & 73.28 & 7.07 \\
\hline & 0 & 2.24 & 708.76 & 24.41 & & 10.16 & 76.84 & 11.16 \\
\hline & 100 & 2.08 & 957.51 & 36.05 & & 15.30 & 54.75 & 9.77 \\
\hline & 300 & 2.83 & 798.95 & 32.56 & & 10.11 & 57.99 & 10.66 \\
\hline & 500 & 3.64 & 873.62 & 21.54 & & 8.73 & 71.45 & 10.96 \\
\hline K3 & Mean & 2.82 & 834.71 & 28.37 & & 11.00 & 64.93 & 10.64 \\
\hline & 100 & 1.74 & 497.26 & 28.36 & & 14.18 & 76.16 & 6.22 \\
\hline & 300 & 2.83 & 690.66 & 40.08 & & 30.38 & 53.58 & 4.53 \\
\hline & 500 & 3.09 & 915.79 & 64.04 & & 22.97 & 60.03 & 5.69 \\
\hline & Mean & 2.53 & 675.13 & 46.93 & & 22.61 & 60.81 & 5.32 \\
\hline
\end{tabular}


Table 4. Mangrove vegetation and aerial root for each station (Bp: Bruguiera parviflora, Ra: Rhizophora apiculata, Rm: Rhizophora mucronata, Bg: Bruguiera gymnorrhiza, Bs: Bruguiera sexangular, Hl: Heritiera littoralis, Xg: Xylocarpus granatum. The sequence is based on the highest dominance).

\begin{tabular}{|c|c|c|c|c|c|c|c|}
\hline Station & $\begin{array}{l}\text { Distance } \\
(\mathrm{m})\end{array}$ & $\begin{array}{l}\text { Mangrove } \\
\text { Species }\end{array}$ & $\begin{array}{l}\text { Mean of Relative } \\
\text { Density }\left(\mathrm{ha}^{-1}\right)\end{array}$ & $\begin{array}{l}\text { Mean of Basal } \\
\text { Area }\left(\mathrm{cm}^{2} \mathrm{ha}^{-1}\right)\end{array}$ & $\begin{array}{l}\text { Mean of } \\
\text { roots }\left(\mathrm{m}^{-2}\right)\end{array}$ & $\begin{array}{c}\text { Mean of } \\
\text { diameter }(\mathrm{mm})\end{array}$ & $\begin{array}{l}\text { Mean of root } \\
\text { area }\left(\mathrm{cm}^{2} \mathrm{~m}^{-2}\right)\end{array}$ \\
\hline \multirow[t]{4}{*}{$\mathrm{K} 1$} & 0 & $\mathrm{Bp}, \mathrm{Ra}, \mathrm{Rm}$ & 675 & 46.8 & 14 & 28.4 & 418.2 \\
\hline & 100 & $\mathrm{Ra}, \mathrm{Rm}$ & 200 & 46.1 & 18 & 29.3 & 583.9 \\
\hline & 300 & $\mathrm{Bg}, \mathrm{Bp}, \mathrm{Ra}$ & 475 & 49.7 & 12 & 33.6 & 485.0 \\
\hline & 500 & $\mathrm{Bg}, \mathrm{Bs}, \mathrm{HI}, \mathrm{Ra}, \mathrm{Xg}$ & 300 & 51.7 & 13 & 26.4 & 329.1 \\
\hline \multirow[t]{4}{*}{$\mathrm{K} 2$} & 0 & $\mathrm{Bp}, \mathrm{Ct}, \mathrm{Ra}, \mathrm{Xm}$ & 200 & 15.0 & 25 & 16.5 & 361.7 \\
\hline & 100 & $\mathrm{Bg}, \mathrm{Ba}, \mathrm{Bp}$ & 225 & 20.5 & 28 & 35.2 & 2139.4 \\
\hline & 300 & $\mathrm{Bg}, \mathrm{Ra}$ & 350 & 25.2 & 24 & 26.4 & 618.2 \\
\hline & 500 & $\mathrm{Bg}, \mathrm{Bs}, \mathrm{Ra}$ & 200 & 26.5 & 20 & 32.5 & 886.1 \\
\hline \multirow[t]{4}{*}{ K3 } & 0 & $\mathrm{Bp}, \mathrm{Ra}$ & 400 & 31.8 & 12 & 20.7 & 203.9 \\
\hline & 100 & $\mathrm{Bp}, \mathrm{Ra}$ & 300 & 23.2 & 34 & 22.7 & 586.5 \\
\hline & 300 & $\mathrm{Bg}, \mathrm{Bp}, \mathrm{Ra}$ & 375 & 40.1 & 12 & 33.4 & 452.8 \\
\hline & 500 & $\mathrm{Ra}$ & 150 & 25.1 & 18 & 22.2 & 325.5 \\
\hline
\end{tabular}

The aerial root structures influence sedimentation by creating a greater amount of friction during flowing tides and then settling out during slowing or ebbing tides (Krauss et al., 2003). The plant structure also reduces the water velocity, and stagnant zones are created between roots and trunks (Mackenzie et al., 2015). This study showed that higher relative density and higher basal area reduce sediment accretion (Figure 8). This is consistent with the analysis of Krauss et al. (2003), based on the study of Spenceley (1977), who concluded that root density may create more turbulence at aerial roots and promote erosion instead of deposition. The diameter of the aerial roots also had a negative correlation with sedimentation. Since the most of mangrove vegetation was
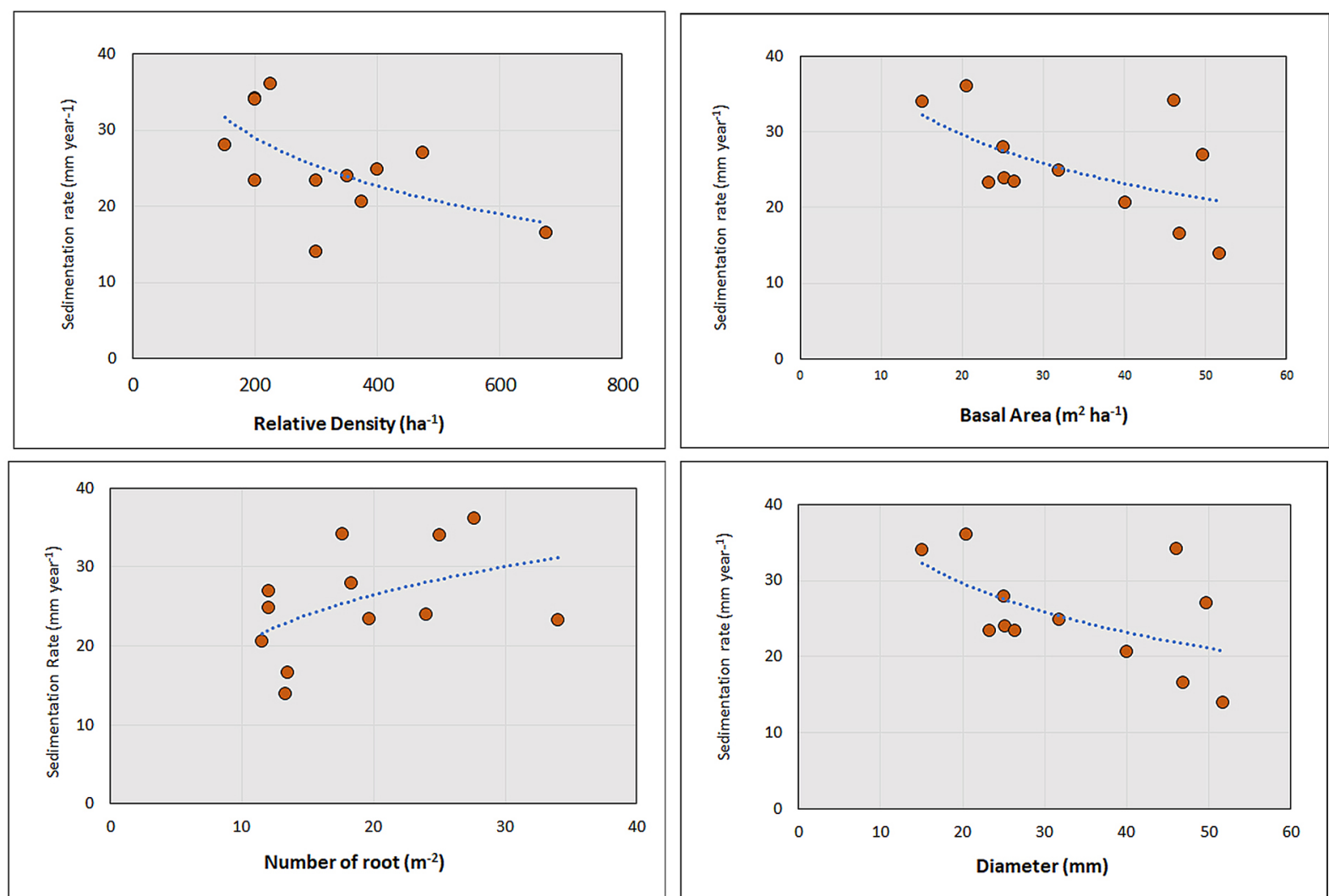

Figure 8. The correlations of relative density, basal area, mean of roots and diameter with sedimentation accretion 
a)

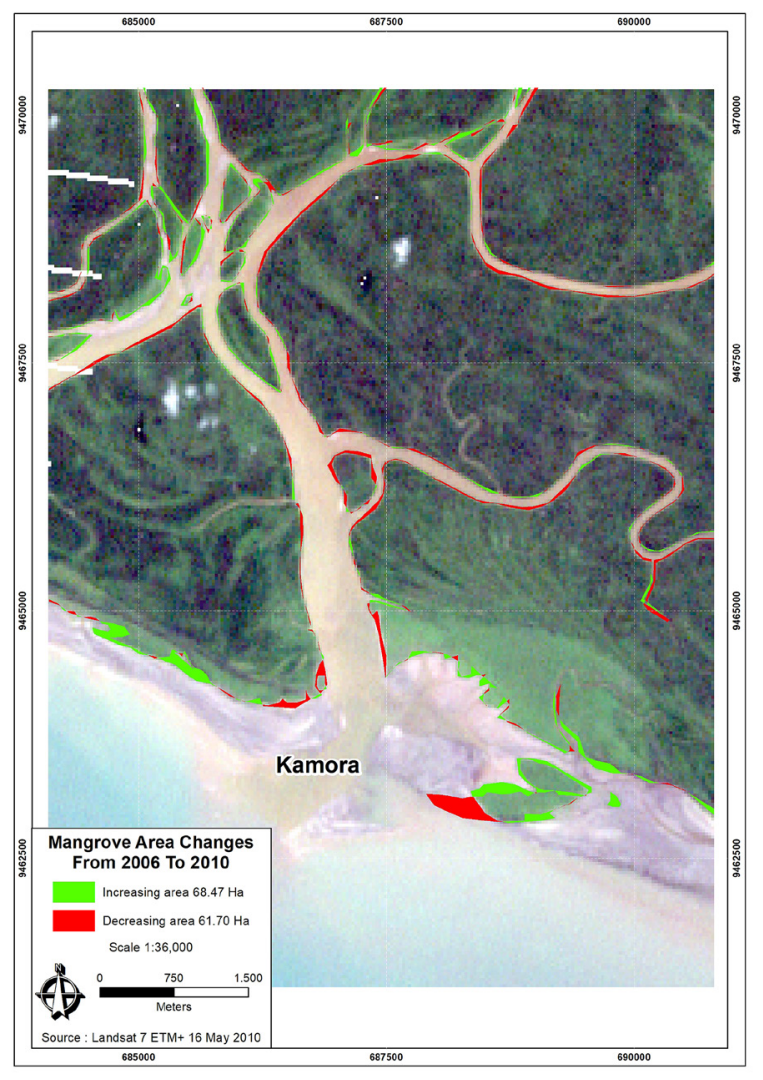

b)

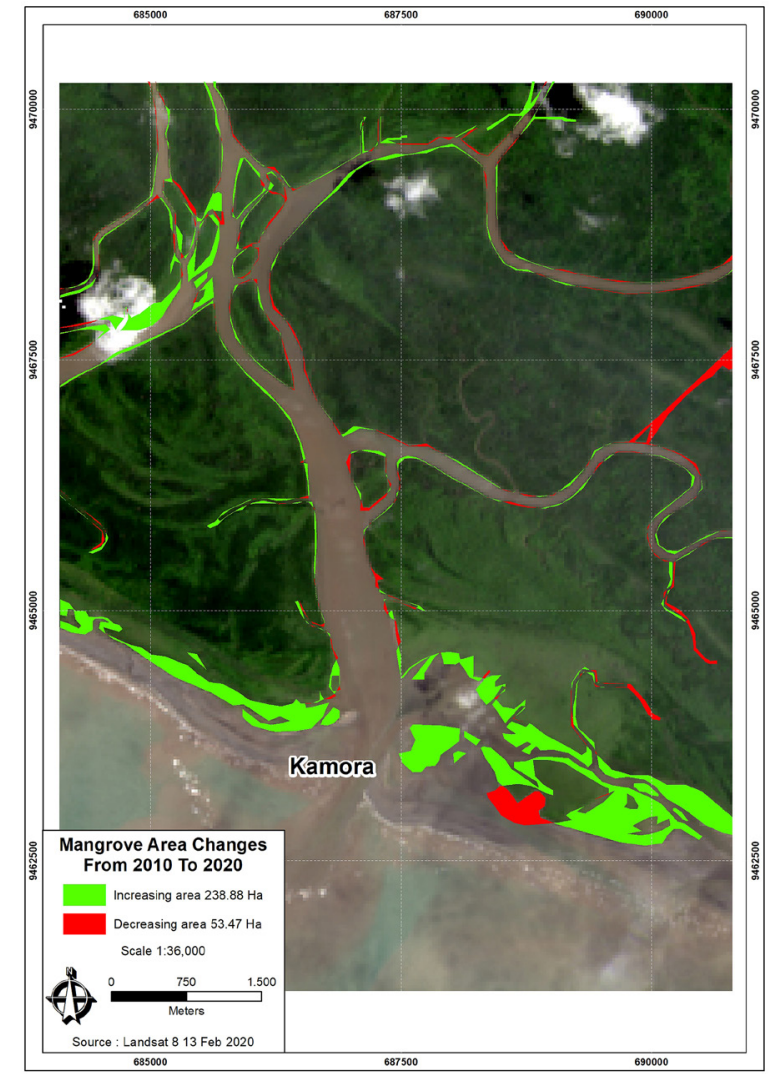

c)

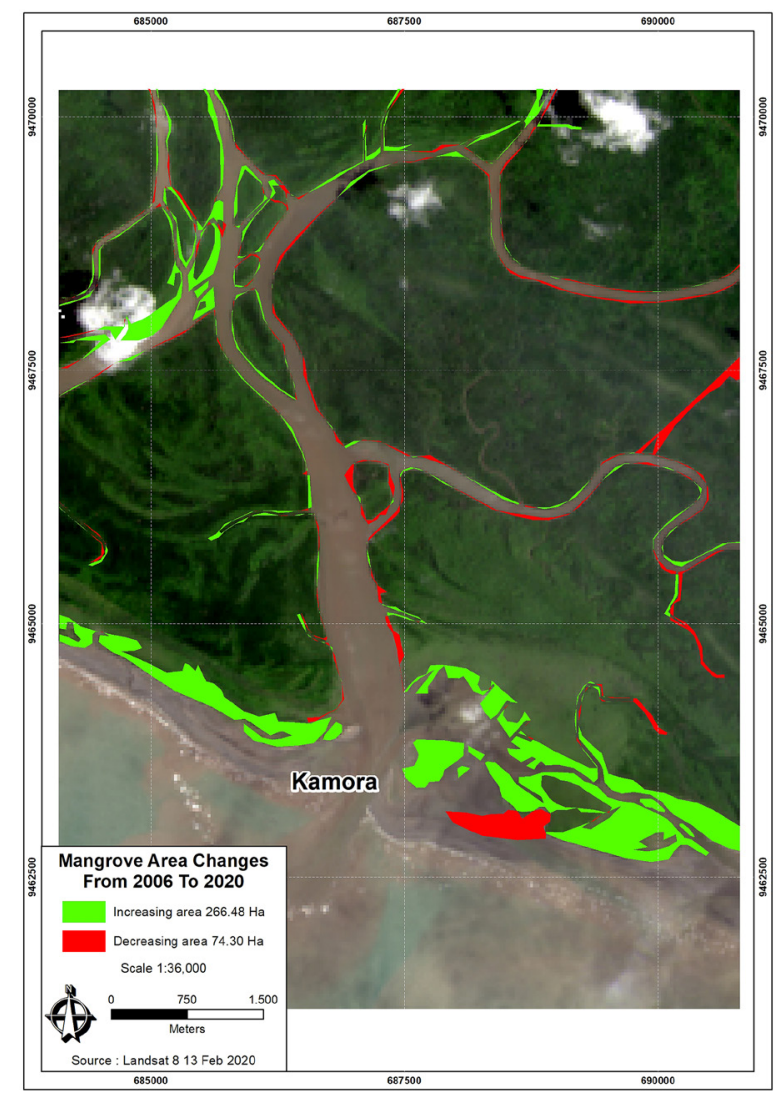

Figure 9. Spatial analysis of the mangrove area changes in the Kamora Estuary, Mimika, Papua, from 2006 to 2020. 
Bruguiera or Rhizophora, this study suggests that the prop roots of Rhizophora, which have a lower diameter than the knee roots of Bruguiera, are more effective at trapping sediment. Krauss et al. (2003) also demonstrated that the prop roots of Rhizophora facilitate greater sediment deposition than other knee roots and pneumatophores.

The sedimentation accumulation in the upper stream was greater compared to the lower stream of the estuary, as shown in Table 1. This is consistent with the study of Woodroffe et al. (2016), where the riverine area had the highest vertical accretion compared with the scrub or overwash. The different results for the sediment stakes and sediment traps suggest that the downstream mangroves with lower elevation experience greater erosion due to frequent tidal pumping. On the basis of the elevation measurement, K3 had a lower elevation than $\mathrm{K} 1$, causing it to experience more frequent inundation. According to Horstman (2015), deposition rates are significantly affected by relative elevation, with the sediment accumulation decreasing with deeper inundation. The sediment trap data show that the sediment inputs were similar, although erosion appears to occur in the more downstream area.

Another factor causing higher sedimentation accumulation at the upstream location was particle size. $\mathrm{K} 1$ is the only location that had a particle size $>125 \mu \mathrm{m}$. A higher particle size reduces erosion, in line with Lovelock (2015), who determined that the rates of surface elevation gain are high for sandy sediments. Larger particles have faster settling velocity of the sediment and need more energy for erosion or resuspension ,due to the relationship between the settling velocity and particle size, as determined by Graham and Smith (2010). The higher particles stem from the sediment load of the Kamora River, as shown by the high TSS data in Figure 4, ranging from 1 to $2,560 \mathrm{mg} / \mathrm{L}$ with an average of $172 \mathrm{mg} \mathrm{L}^{-1}$. According to Puri Fajar Mandiri (2002), the Kamora River has a catchment area of $1,475 \mathrm{~km}^{2}$ with a river flow of $287-1700 \mathrm{~m}^{3} \mathrm{~s}^{-1}$ and a TSS of 32-1700 $\mathrm{mg} \mathrm{L}^{-1}$. The estimated sediment loading ranges from 366 to 160,752 ton day $^{-1}$. With a flow average of $300 \mathrm{~m}^{3} \mathrm{~s}^{-1}$ and a TSS of $172 \mathrm{mg} \mathrm{L}^{-1}$, an estimated 4.458 ton day ${ }^{-1}$ of sediment are deposited in the estuary and marine area. Due to the gravitation, the larger particles settle in the upper estuary and the fine particles continue and settle in the downstream area.

The total organic carbon accumulation in this study was $736.8 \mathrm{~g} \mathrm{~m}^{2}$ yearr $^{-1}$, which is relatively high compared with the global average mangrove carbon burial of $174 \mathrm{~g} \mathrm{~m}^{2}$ year-1 (Alongi, 2012). This study also found greater carbon accumulation than the study by Pérez et al. (2017) in New Zealand $\left(65.5 \pm 16.3 \mathrm{~g} \mathrm{~m}^{2}\right.$ year $\left.{ }^{-1}\right)$ and Aysha et al. (2016) in Bangladesh (83.1 $\mathrm{g} \mathrm{m}^{2}$ year-1), but it was close to the maximum carbon accumulation found in Palau and Vietnam by MacKenzie (2016), which ranged from 69 to $602 \mathrm{~g} \mathrm{~m}^{2}$ year ${ }^{-1}$. A study on carbon storage was carried out by Taberima et al. (2014) in Papua, revealing total carbon storage ranging from 853.23 to $1,311.61 \mathrm{mg}$ $\mathrm{ha}^{-1}$. Another study by Sasmito et al. (2020) in West Papua also found consistent results of 1,087 $\pm 584 \mathrm{mg} \mathrm{C} \mathrm{ha}^{-1}$, whereby the greatest carbon storage was found in estuarine interior mangroves, followed by the open coast interior and the open coast fringe. The results of those studies show that the carbon storage in Papua found in this study is exceptionally high, compared to other mangroves around the world. Organic carbon, as a nutrient source, can alter the competitive balance and affect the species distribution of mangroves (Kathiresan, 2003).

The high sedimentation rate and total organic carbon accumulation contribute to the expansion of mangrove forests. Using spatial analysis, this study concluded that the progression of mangroves is about $0.35 \%$ every year, mainly due to the development of new land at the estuary mouth. The new mangrove area in the past 15 years in the Kamora Estuary amounts to 192.18 ha. Krauss et al. (2003) stated that the root structure of mangroves contributes to the geomorphological stability of the mangrove forest soil through entrapment and sediment binding, which in turn promotes the growth and expansion of mangrove forests. The study in New Zealand by Lundquist et al. (2013) found that mangrove expansion is primarily associated with increased terrestrial sediment erosion and deposition into coastal and estuarine environments. Mangrove expansion has been widely observed on the North Island of New Zealand, at a rate of $0.33 \%$ per year (from 1940 to 2003). The result is very similar to the expansion rate seen in the Kamora Estuary.

\section{CONCLUSIONS}

This study makes an important contribution in determining the mangrove response to rapid sedimentation in Papua, where limited studies 
have been conducted thus far. The results of this study show that sediment accretion and total organic carbon accumulation in the mangrove forest of the Kamora Estuary, Mimika were higher than in other mangrove regions in the world, although they are consistent with the results from Papua New Guinea. The dynamic process of sedimentation was also determined, showing higher sediment accretion on the riverbank, whereby the prop roots of Rhizophora were found to be more effective at trapping sediment compared to the knee roots of Bruguiera. This study also showed a negative correlation between mangrove density and basal area and sedimentation accretion.

The high sedimentation in the Kamora Estuary has resulted in the expansion of the mangrove forest, particularly in the seaward area, due to the deposition of sediment, creating new land that is rapidly colonized by mangroves. Conservation and assisted colonization can be used to expand the mangrove forest, which offers many benefits in terms of coastal stabilization and the provision of habitat for marine fauna. The selection of species can consider the Rhizophora species, as this study has shown that it can promote greater sediment deposition and retention.

\section{Acknowledgements}

We would like to thank PT Freeport Indonesia for the support and facilitation in conducting this study and to the Doctorate Program of Marine Science, Faculty of Fishery and Marine Science, Universitas Diponegoro for the support and facilitation. The authors declare no competing interests.

\section{REFERENCES}

1. Aalto R., Dietrich W. 2005. Sediment accumulation determined with $210 \mathrm{~Pb}$ geochronology for Strickland River flood plains, Papua New Guinea. Sediment Budgets I, Proceedings of symposium S1 held during the Seventh IAHS Scientific Assembly at Foz do Iguaçu, Brazil. IAHS Publ. 291.

2. Adame M.F., Neil D., Wright S.F., Lovelock C.E. 2010. Sedimentation within and among mangrove forests along a gradient of geomorphological settings. Estuarine, Coastal and Shelf Science, $86,21-30$.

3. Aller R.C., Blair N.E. 2004. Early diagenetic remineralization of sedimentary organic $\mathrm{C}$ in the Gulf of Papua deltaic complex (Papua New Guinea): Net loss of terrestrial $\mathrm{C}$ and diagenetic fractionation of $\mathrm{C}$ isotopes. Geochimica et Cosmochimica Acta, 68(8), 1815-1825.

4. Alongi D.M., Pfitzner J., Trott L.A., Tirendi F., Dixon P., Klumpp D.W. 2005. Rapid sediment accumulation and microbial mineralization in forests of the mangrove Kandelia candel in the Jiulongjiang Estuary, China. Estuarine, Coastal and Shelf Science, 63(4), 605-618.

5. Alongi D.M. 2012 Carbon sequestration in mangrove forests, Carbon Management, 3(3), 313-322. DOI: $10.4155 / \mathrm{cmt} .12 .20$

6. Aslan A., Rahman A.F. Robesond S.M. 2018. Investigating the use of Alos Prism data in detecting mangrove succession through canopy height estimation. Ecological Indicator, 87, 136-143.

7. Aysha A., Abu Hena M.K., Mishra M., Nesarul M.H., Padhi B.K., Mishra S.K., Islam M.S., Idris M.H., Masum M.B. 2015. Sediment and carbon accumulation in sub-tropical salt marsh and mangrove habitats of north-eastern coast of Bay of Bengal, Indian Ocean. International Journal of Fisheries and Aquatic Studies, 2(4), 184-189.

8. Banerjee K., Senthilkumar B., Purvaja R. et al. 2012. Sedimentation and trace metal distribution in selected locations of Sundarbans mangroves and Hooghly estuary, Northeast coast of India. Environ Geochem Health, 34, 27-42. https://doi. org/10.1007/s10653-011-9388-0

9. Brunskill G.J., Zagorskis I., Pfitznera J., Ellison J. 2004. Sediment and trace element depositional history from the Ajkwa River estuarine mangroves of Irian Jaya (West Papua), Indonesia. Continental Shelf Research, 24, 2535-2551.

10. Bomer E.J., Wilson C.A., Hale R.P., Hossain A.N.M., Arifur Rahman F.M. 2019. Surface elevation and sedimentation dynamics in the GangesBrahmaputra tidal delta plain, Bangladesh: Evidence for mangrove adaptation to human-induced tidal amplification. CATENA, 187, 104312. DOI: 10.1016/j.catena.2019.104312.

11. Davies H. 2012. The geology of New Guinea - the cordilleran margin of the Australian continent. Episodes, 35(1), 87-102.

12. Ellison J.C. 1999. Impacts of sediment burial on mangroves. Marine Pollution Bulletin, 37(8-12), 420-426.

13. Ellison J.C. 2005. Holocene palynology and sealevel change in two estuaries in Southern Irian Jaya. Paleogeography, Paleoclimatology, Paleoecology, 220(3-4), 291-309.

14. Ewe K., Twilley R., Ong J. 2008. Different kinds of mangrove forests provide different goods and services. Global Ecology \& Biogeography Letters, 7(1), 83-94.

15. Graham G.W., Smith A.M.N. 2010. The application of holography to the analysis of size and settling 
velocity of suspended cohesive sediments. Limnology and Oceanography: Methods, 8, 1-15. DOI: 10.4319/lom.2010.8.1

16. Hanum I.F., Latiff A., Hakeem K.R., Ozturk M. 2014. Mangrove ecosystems of Asia: status, challenges and management strategies. Springer.

17. Horstman E.M., Dohmen-Janssen C.M., Bouma T.J., Hulscher S.J.M.H. 2015. Tidal-scale flow routing and sedimentation in mangrove forests: Combining field data and numerical modelling. Geomorphology, 228, 244-262. DOI: 10.1016/j. geomorph.2014.08.011.

18. Kastoro W.W., Amiruddin, Azis A., Aswandi I., Al Hakim I., Lala D., Setyadi G. 2007. Macroenthic community structures of the offshore area of Mimika District, Papua. Mar. Res. Indonesia, 32(2), 109-121.

19. Kathiresan K., Bingham B.L. 2001. Biology of mangroves and mangrove ecosystems. Advances in Marine Biology, 40, 81-251.

20. Kathiseran K. 2003. How do mangrove forests induce sedimentation? Revista de Biología Tropical, 51(2).

21. Krauss K.W., Allen J.A., Cahoon D.R. 2003. Differential rates of vertical accretion and elevation change among aerial root types in Micronesian mangrove forests. Estuarine, Coastal and Shelf Science, 56, 251-259.

22. Li R., Chai M., Guo M., Qiu G.Y. 2016. Sediment accumulation and mercury $(\mathrm{Hg})$ flux in Avicennia marina forest of Deep Bay, China. Estuarine, Coastal and Shelf Science, 177, 41-46. DOI: 10.1016/j. ecss.2016.05.005.

23. Lovelock C.E., Adame M.A.F., Bennion V., Hayes M., Reef R., Santini N., Cahoon D.R. 2015. Sea level and turbidity controls on mangrove soil surface elevation change. Estuarine, Coastal and Shelf Science, 153, 1-9. DOI: 10.1016/j.ecss.2014.11.026.

24. Lundquist C., Morrisey D., Gladstone-Gallagher R., Swales A. 2014. Managing Mangrove Habitat Expansion in New Zealand. In: Faridah-Hanum I., Latiff A., Hakeem K., Ozturk M. (eds) Mangrove Ecosystems of Asia. Springer, New York, NY. DOI: 10.1007/978-1-4614-8582-7_19

25. MacKenzie R.A., Foulk P.B., Klump J.V. et al. 2016. Sedimentation and belowground carbon accumulation rates in mangrove forests that differ in diversity and land use: a tale of two mangroves. Wetlands Ecol Manage, 24, 245-261. DOI:10.1007/ s11273-016-9481-3

26. McKee K.M. 2011. Biophysical controls on accretion and elevation change in Caribbean mangrove ecosystems. Estuarine, Coastal and Shelf Science, 91, 475-483.

27. Marchio Jr D.A., Savarese M., Bovard B., Mitsch W.J.2016. Carbon sequestration and sedimentation in mangrove swamps influenced by hydrogeomorphic conditions and urbanization in Southwest Florida. Forests, 7, 116.

28. Morelli G., Gasparon M., Fierro D., Hu W.P., Zawadzki A. 2012. Historical trends in trace metal and sediment accumulation in intertidal sediments of Moreton Bay, southeast Queensland, Australia. Chemical Geology, 300-301. DOI:10.1016/j. chemgeo.2012.01.023.

29. Pérez A., Machado W., Gutierrez D., Stokes D., Sanders L., Smoak J.M., Santos I., Sanders C.J. 2017. Changes in organic carbon accumulation driven by mangrove expansion and deforestation in a New Zealand estuary. Estuarine, Coastal and Shelf Science, 192, 108-116.

30. Phan L.K., van Thiel de Vries J.S.M., Stive M.J.F. 2015. Coastal mangrove squeeze in the Mekong Delta. Journal of Coastal Research, 31(2), 233-243. DOI: 10.2112/JCOASTRES-D-14-00049.1.

31. Puri Fajar Mandiri P.T. 2002. Discharge measurement at rivers in the vicinity of the COW area of PTFI, June - August 2001. PT. Puri Fajar Mandiri, Engineering dan Business Consultants, Jakarta (Unpublished Report).

32. Rogers K.G., Goodbred S.L., Mondal D.R. 2013. Monsoon sedimentation on the 'abandoned' tideinfluenced Ganges-Brahmaputra delta plain. Estuar. Coast. Shelf Sci., 131, 297-309, DOI: 10.1016/j. ecss.2013.07.014.

33. Santen P.V., Augustinus P.G.E.F., Janssen-Stelder B.M., Quartel S., Tri N.H. 2007. Sedimentation in an estuarine mangrove system. Journal of Asian Earth Sciences, 29, 566-575.

34. Sasmito S.D., Sillanpää M., Hayes M.A., Bachri S., Saragi-Sasmito M.F., Sidik F., Hanggara B.B., Mofu W.Y., Rumbiak V.I., Hendri, et al. 2020. Mangrove blue carbon stocks and dynamics are controlled by hydrogeomorphic settings and land-use change. Glob. Change Biol., 26, 3028-3039.

35. Setyadi G., Kastoro W.W., Rahayu D.L., Haris A., Dwiono S.A.P., Kailola P. 2009. Biota akuatik di perairan Mimika Papua. PT Freeport Indonesia and Research Center for Oceanography - Indonesian Institute of Sciences.

36. Sidik F., Neil D., Lovelock C.E. 2016. Effect of high sedimentation rates on surface sediment dynamics and mangrove growth in the Porong River, Indonesia. Marine Pollution Bulletin, 107(1), 355-363.

37. Smoak J.M., Patchineelam S.R. 1999. Sediment mixing and accumulation in a mangrove ecosystem: evidence from 210Pb, 234Th and 7Be. Mangroves and Salt Marshes 3, 17-27. Kluwer Academic Publishers.

38. Smoak J.M., Breithaupt J.L., Smith T.J., Sanders C.J. 2013. Sediment accretion and organic carbon burial relative to sea-level rise and storm events in two mangrove forests in Everglades National Park, CATENA, 
104, 58-66. DOI:10.1016/j.catena.2012.10.009.

39. Stokes D.J., Healy T.R., Cooke P.J. 2009. Surface elevation changes and sediment characteristics of intertidal surfaces undergoing mangrove expansion and mangrove removal, Waikaraka Estuary, Tauranga Harbour, New Zealand. International Journal of Ecology dan Development, 12(WO9), 88-106.

40. Swales A., Bentley S.J., Lovelock C., Bell R.G. 2007. Sediment processes and mangrove- habitat expansion on a rapidly-prograding Muddy Coast, New Zealand. Sixth International Symposium on Coastal Engineering and Science of Coastal Sediment Process, 1441-1454.

41. Swales A., Bentley S.J., Lovelock C.E. 2015. Mangrove-forest evolution in a sediment-rich estuarine system: opportunists or agents of geomorphic change? Earth Surface Processes and Landforms, 40(12), 1672-1687.

42. Swales A., Lovelock C.E. 2020. Comparison of sediment-plate methods to measure accretion rates in an estuarine mangrove forest (New Zealand),
Estuarine, Coastal and Shelf Science, 236, 106642. DOI: 10.1016/j.ecss.2020.106642.

43. Taberima S., Nugroho Y.D., Murdiyarso D. 2014. The Distribution of Carbon Stock in Selected Mangrove Ecosystem of Wetlands Papua: Bintuni, Teminabuan, and Timika, Eastern Indonesia. International Conference on Chemical, Environment \& Biological Sciences (CEBS-2014) Sept. 17-18, 2014 Kuala Lumpur (Malaysia).

44. Walsh J.P., Nittrouer. 2004. Mangrove-bank sedimentation in a mesotidal environment with large sediment supply, Gulf of Papua. Marine Geology, 208(2-4), 225-248.

45. Willemsen P.W.J.M., Horstman E.M., Borsje B.W., Friess D.A., Dohmen-Janssen C.M. 2016. Sensitivity of the Sediment Trapping capacity of an estuarine mangrove forest. Geomorphology, 273, 189-201.

46. Woodroffe C.D., Rogers K., McKee K.L., Lovelock C.E., Mendelssohn I.A., Saintilan N. 2016. Mangrove sedimentation and response to relative sea-level Rise. Annual Review of Marine Science, 8(1), 243-266. 